\title{
A Decision Method to Maximize Service Quality under Budget Constraints: The Kano Study of a Chinese Machinery Manufacturer
}

\author{
Qingliang Meng, ${ }^{1,2}$ Xiaochao Wei, ${ }^{3}$ and Wen Meng ${ }^{4}$ \\ ${ }^{1}$ School of Management \& Economics, Jiangsu University of Science and Technology, Zhenjiang, Jiangsu 212003, China \\ ${ }^{2}$ Business School, Hunan University, Changsha, Hunan 410082, China \\ ${ }^{3}$ School of Economics, Wuhan University of Technology, Wuhan, Hubei 430070, China \\ ${ }^{4}$ Marketing Department, Xuzhou Construction Machinery Group Co., Ltd., Xuzhou, Jiangsu 221004, China
}

Correspondence should be addressed to Qingliang Meng; mengzhi007@163.com

Received 27 June 2016; Accepted 5 September 2016

Academic Editor: Xiaofeng Xu

Copyright (C) 2016 Qingliang Meng et al. This is an open access article distributed under the Creative Commons Attribution License, which permits unrestricted use, distribution, and reproduction in any medium, provided the original work is properly cited.

\begin{abstract}
Manufacturers are increasingly facing keen competition and improving customers' position in the value chain. Many of them have made efforts to promote service quality and enhance customer satisfaction. Research is lacking in considering the trade-off between service costs and customer satisfaction when tackling service quality issues in the machinery industry. A decision method is proposed for maximizing service quality in machinery industry under budget constraints, from the perspective of enterprise capacity and customer satisfaction. Due to the strength of the Kano model in acknowledging the nonlinear impacts of quality elements on customer satisfaction, we formalize the relationship between customer satisfaction and sufficiency of service quality elements quantitatively. And then we develop a novel nonlinear programming model to maximize service quality under budget constraints. In particular, we implement our model at Xuzhou Construction Machinery Group Co., Ltd., one of the largest Chinese construction machinery companies, to validate the efficacy of the method.
\end{abstract}

\section{Introduction}

To meet complex customer requirements and respond quickly to increasing competition and technological developments, the machinery industry has recognized customer value as a source of competitive advantage [1]. The machinery industry produces and maintains machines for consumers, the industry, and other companies. Many machinery manufacturers transform themselves from being product-oriented companies to being service providers [2-4]. They believe effective service planning and high level of quality service delivery are necessary to improve operations efficiency and enhance competitive edge [5].

Indeed, the changing environment has led to a lot of machinery manufacturers to rethink their service strategies. The concept of service is not limited to after-sale service, it will be extended to cover the whole lifetime cycle. This includes the service components integrated into the process of delivery, consumption, and use. Researchers have used various expressions to refer to the escalation of services, for example, "servitisation" [6], "integrated solutions" [7], and product-service systems (PSS) [8-11]. Obviously, service is crucial for machine manufacturers to enhance customer value and gain additional business. To gain customer endorsement and loyalty, firms need to put efforts into service design to improve service quality [12].

Oliva and Kallenberg (2003) [2] highlighted the significance of service quality in satisfying and retaining customers in manufacturing industries, while Izogo and Ogba (2015) [12] believe customer's satisfaction of service quality is the determinant of customer loyalty. However, manufacturers offer services of varying scopes and degrees, and the service quality is significantly related to the specific service processes and service participants. To achieve high service quality, 
one needs to understand the relationships between various service quality elements and other related elements, for example, processes, personnel, and resources [13].

The literatures have mainly focused on categorizing customer service requirements, planning, and designing proper service products to assure customer satisfaction. There is a lack of a systematic and quantitative verification scheme for service quality improvement, especially in the machinery industry. In general, services influence costs, and high service quality often leads to high service costs. It is therefore vital to strike a good balance between customer satisfaction and service costs when improving service quality in machinery industries, while researchers have not yet addressed this important issue enough. To make contributions to the existing literatures, we try to find out a solution of service quality improvement in machinery industries to leverage customer satisfaction and budget constraints from bilateral perspectives (customer satisfaction and service provider's capacity). Thus, the relationships between customer satisfaction, service costs, and service quality elements will be identified, and then a novel quantitative decision method will be set up to determine the priorities of service quality elements in quality improvement.

In an effort to propose a decision method to maximize the overall customer satisfaction under budget constraints, we formulate two research issues:

(1) In the machinery industry there is a limit on resources allocation to services. Most resources are focused on tangible products. There is still a need for a continuous improvement process in regard to service quality. So based on a bilateral prospective, how can this help to develop a systemic and quantitative framework to identify key service quality elements, detect the relationship among quality elements, and determine the improvement priorities for service transformation in machinery industries?

(2) The level of customer satisfaction depends on adequate supply of the service components, which relies on large monetary investment. Then, how can this help to develop a mathematical model balancing customer satisfaction and service costs and validate the results empirically?

The paper proceeds as follows. Section 2 covers a review of the literatures. Section 3 proposes the research framework. We implement the proposed model and its solution methodology to Xuzhou Construction Machinery Group Co., Ltd. (XCMG), the largest construction machinery company in China, in Section 4 and prove its validity. Research conclusions and future research are discussed in Section 5.

\section{Literature Review}

2.1. Kano's Model. Kano et al. (1984) [14] proposed the Kano model adapting Herzberg's "motivation-hygiene theory" [15]. This model demonstrates the nonlinear relationship between customer satisfaction and the performance of quality elements. And it classifies quality elements into five dimensions: must-be, one-dimensional, attractive, indifferent, and reverse, as shown in Figure 1.

The Kano model has been widely used for customers' needs analysis, decision-making analysis, and other management practices [16-18]. However, it has some disadvantages; that is, it uses qualitative analysis techniques and does not define the classification criteria explicitly in quality elements' classification. It also fails to account for the provider's concerns in terms of the capacity to fulfill the customer requirements [17].

Many studies tried to improve Kano's model for supporting product and service design in different ways. Through the quantitative analysis of Kano's model, Berger et al. (1993) [19] used two indicators of customer satisfaction (CS) and customer dissatisfaction (DS) to indicate the average impact of customer requirements on customer satisfaction. This improves Kano's model in understanding the influence about different categories of customer requirements on CS [20]. Further, Wang and Ji (2010) [21] proposed a novel approach to identify the relationships between customer satisfaction and the fulfillment of customer requirements (S-CR) in Kano's model, and it provided an effective way to integrate Kano's model to other mathematical model in engineering design process.

In addition, the traditional Kano survey forces customers to choose one answer for a particular question. This ignores the fuzzy and uncertainty factors related to human thinking when the questionnaire is being designed. Thus, some scholars proposed the fuzzy Kano model using integrated fuzzy set theory [22-24].

To improve Kano's model for decision support, literatures discussed the issues of integrating Kano model with other techniques. These techniques include SERVQUAL [25, 26], QFD [27-29], Importance-Performance Analysis (IPA) [30], and Kaisei engineering [31, 32]. It is very beneficial for improving Kano methodology [33].

2.2. Kano's Model in Service Quality Management. Understanding each category of the quality elements will be helpful in service quality management. Thus, the Kano model has been applied in various industries to classify service quality elements and make decisions in improving service quality. An overview of the reviewed literature in this theme is given in Table 1, encompassing authors, research focus, industry, and model type (theory, quantitative method, or empirical).

Previous research in the area has shown focus on service quality elements identification, evaluation, and classification. There has not been an emphasis on the decision-making method of service quality improvement. The small amount of research in this area dealt with qualitative analysis, and there is a dearth of quantitative research. Table 1 shows that the Kano model has a wide application in improving service quality in many industries. However, most of these applications are in the service business, and little research is focused on service quality in machinery enterprises. 


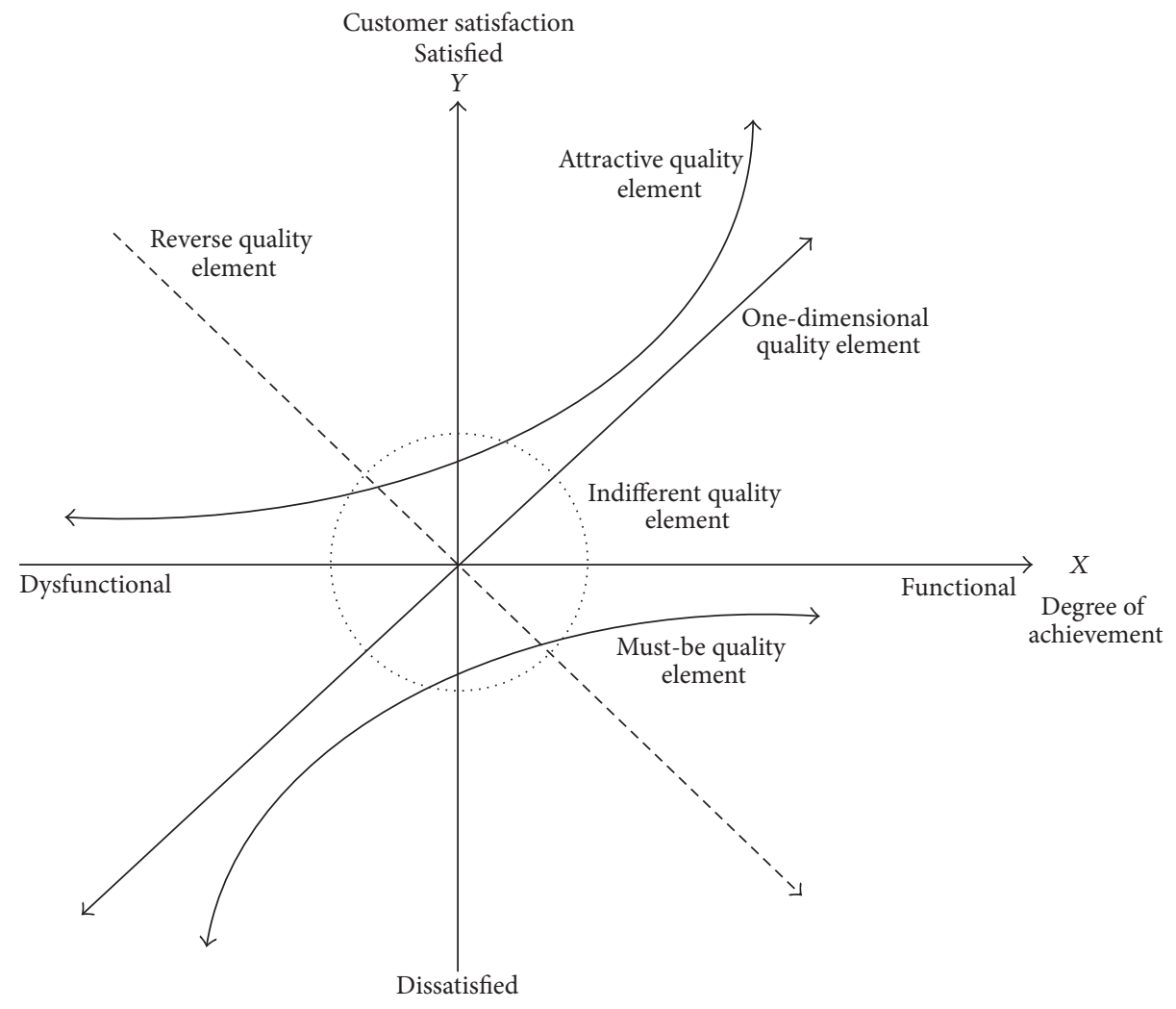

Figure 1: An overview of Kano model.

2.3. Conclusions on the Literatures. From the review of related literatures the following conclusions were drawn:

(1) The Kano model is an effective tool to identify and classify service quality elements whether in service product development or service quality improvement. But Kano model is still a qualitative method in nature, and setting up a quantitative Kano methodology would be beneficial to provide support for decisions more effectively.

(2) Service quality research has largely been focused on service business, leading to a dearth of research on service quality in machinery industries. Service quality is a critical element for machinery industries to gain and maintain competitive advantage, so it is meaningful to extend the application to machinery industries.

(3) Researchers stressed the importance of understanding service quality elements that have the greatest impact on customer satisfaction and promoting the priority of these quality elements. In the decisionmaking process for service quality improvement, the service provider's capacity needs to also be considered. Cost constraints are usually accommodated in the decision-making. The goal of the decisionmaking process is to seek a solution of service quality improvement that leverages customer satisfaction and the service provider's resource constraints.

\section{Methodology}

In this section, an integrated framework is proposed to maximize machinery industry service quality under budget constraints, by considering the trade-off between customer satisfaction and service costs. Figure 2 shows the proposed research framework with its subprocesses. These subprocesses include identification of service quality elements, division of market segmentation, Kano model survey, quantitative analysis of Kano model, and decision model formulation.

3.1. Identification of Service Quality Elements. Service quality elements extraction and identification are the foundation not only of the Kano model, but also of decision analysis in service quality improvement. Service qualities are different from general products with the distinctive features of intangibility, inseparability, heterogeneity, and perishability [53]. So it is very necessary to find an effective way to translate customer requirements into a set of service quality elements from the customer perspective. There are several methods that can be used to identify customer service quality elements, such as SERVQUAL model and QFD, which are currently thought of as useful methods to extract service quality elements by listening to the voice of customers [29].

3.2. Division of Market Segments. The division of market segments aims to find the appropriate target customers in the decision analysis process. As a rule, different customers have different utility expectations of service quality. At this point, the customer base is divided into several customer segments 
TABLE 1: An overview of the reviewed literatures in this theme.

\begin{tabular}{|c|c|c|c|}
\hline Authors & Research focus & Industry & Model type \\
\hline Tan and Shen (2000) [27] & Integrating Kano model of QFD & Web page & Quantitative method \\
\hline $\begin{array}{l}\text { Erto and Vanacore (2002) } \\
\text { [34] }\end{array}$ & Service quality measurement & Hotel service quality & Empirical \\
\hline Ting and Chen (2002) [35] & Quality elements identification and classification & Hypermarket & Empirical \\
\hline Kuo (2004) [30] & Classification of service quality attributes & $\begin{array}{l}\text { Virtual community } \\
\text { websites }\end{array}$ & Empirical \\
\hline Yang (2005) [36] & Classification of service quality attributes & Technical products & Theory \\
\hline $\begin{array}{l}\text { Nilsson Witell and Fundin } \\
\text { (2005) [37] }\end{array}$ & Dynamics of service attributes & E-service & Theory, empirical \\
\hline Chang et al. (2006) [38] & $\begin{array}{l}\text { Service quality improvement from customers' } \\
\text { satisfaction perspective }\end{array}$ & Hospital services & Quantitative method \\
\hline Chen et al. (2010) [39] & $\begin{array}{l}\text { Service quality improvement by integrating Kano model } \\
\text { of Six-Sigma }\end{array}$ & Stationary industry & Quantitative method \\
\hline Chen and Lee (2009) [40] & Quality elements identification and classification & Chain convenient stores & Method, empirical \\
\hline Kuo et al. (2009) [41] & Service quality measurement and classification & $\begin{array}{l}\text { Mobile value-added } \\
\text { services }\end{array}$ & Theory, empirical \\
\hline Chen et al. (2009) [42] & Attractive quality elements discovering & $\begin{array}{l}\text { Massively multiplayer } \\
\text { online role-playing game }\end{array}$ & Method, empirical \\
\hline Yang (2011) [43] & Quality elements identification & $\begin{array}{l}\text { International certification } \\
\text { service }\end{array}$ & Theory, empirical \\
\hline Xie et al. (2010) [44] & Quality elements evaluation & NPO products & Empirical \\
\hline Chen and Kuo (2011) [45] & Quality elements identification and classification & E-learning service & Empirical \\
\hline Tsai et al. (2011) [46] & Potential service quality gaps discovery & $\begin{array}{l}\text { Human resource service } \\
\text { online agency }\end{array}$ & Method, empirical \\
\hline Kuo et al. (2012) [47] & $\begin{array}{l}\text { Service quality improvement decision using IPA-Kano } \\
\text { model }\end{array}$ & Mobile service & Method, empirical \\
\hline $\begin{array}{l}\text { Florez-Lopez and } \\
\text { Ramon-Jeronimo (2012) } \\
{[48]}\end{array}$ & $\begin{array}{l}\text { Quality elements identification and classification using } \\
\text { fuzzy Kano model }\end{array}$ & Logistics service & Quantitative method \\
\hline $\begin{array}{l}\text { Tontini and Dagostin } \\
\text { Picolo (2014) [49] }\end{array}$ & $\begin{array}{l}\text { Quality elements interaction analysis based on } \\
\text { psychological foundations }\end{array}$ & $\begin{array}{l}\text { Pizzerias and video rental } \\
\text { stores }\end{array}$ & Theory, empirical \\
\hline $\begin{array}{l}\text { F.-Y. Chen and S.-H. Chen } \\
\text { (2014) [50] }\end{array}$ & Service quality improvement & Hot spring industry & Method, empirical \\
\hline $\begin{array}{l}\text { Bandyopadhyay et al. } \\
\text { (2015) [51] }\end{array}$ & Classification of service quality attributes & Banking & Empirical \\
\hline Esmaeili et al. (2015) [52] & $\begin{array}{l}\text { A fuzzy method to assess and identify service quality } \\
\text { attributes }\end{array}$ & Logistics service & Quantitative method \\
\hline Meng et al. (2015) [24] & Decision method for service quality improvement & Logistics service & Method, empirical \\
\hline
\end{tabular}

according to their demographic information, psychographic data, and purchase behaviors. The different customer segments have distinguished characteristics about service quality perceptions. Effective marketing research and customertailored management actions are taken for each segment, guaranteeing an optimal level of customer satisfaction in different customer segments under budget constraints. Many methods and tools are available to assist the process including clustering, classification, self-organizing maps (SOM), evolutionary algorithms, interaction detection methods, and artificial neural networks [54].

3.3. Classification of Service Quality Elements Using the Fuzzy Kano Model. The Kano model provides a systematic way of service quality elements classification. It is based on three tools: the Kano questionnaire, the Kano evaluation table, and the Kano final results table [14]. The Kano questionnaire examines each service quality element with a pair of questions, functional and dysfunctional. There are five possible answers for each question, that is, "like," "must-be," "neutral," "live-with," and "dislike" [14]. According to the Kano evaluation table, for each respondent, the service quality element is classified as one of Kano categories. Generally, according to the Kano final results table, the most frequent observations of the sample set of responses are considered as the final category for the service quality element [14].

Generally, the traditional Kano model is lacking in processing the vagueness and uncertainties in human judgment and decision-making when surveying. Fuzzy set theory introduced by Zadeh (1965) has many advantages in analyzing 
(1) Identification of service quality elements

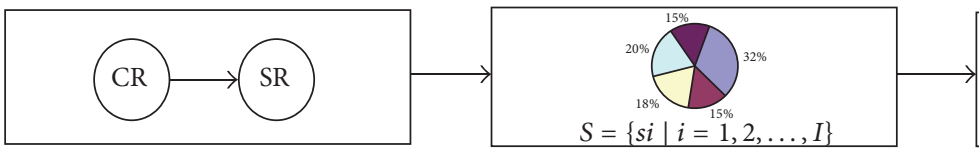

$S=\{s i \mid i=1,2, \ldots, I$
(3) Classification of service quality elements based on fuzzy Kano model

(i) Fuzzy Kano questionnaire

(ii) Fuzzy Kano statistics

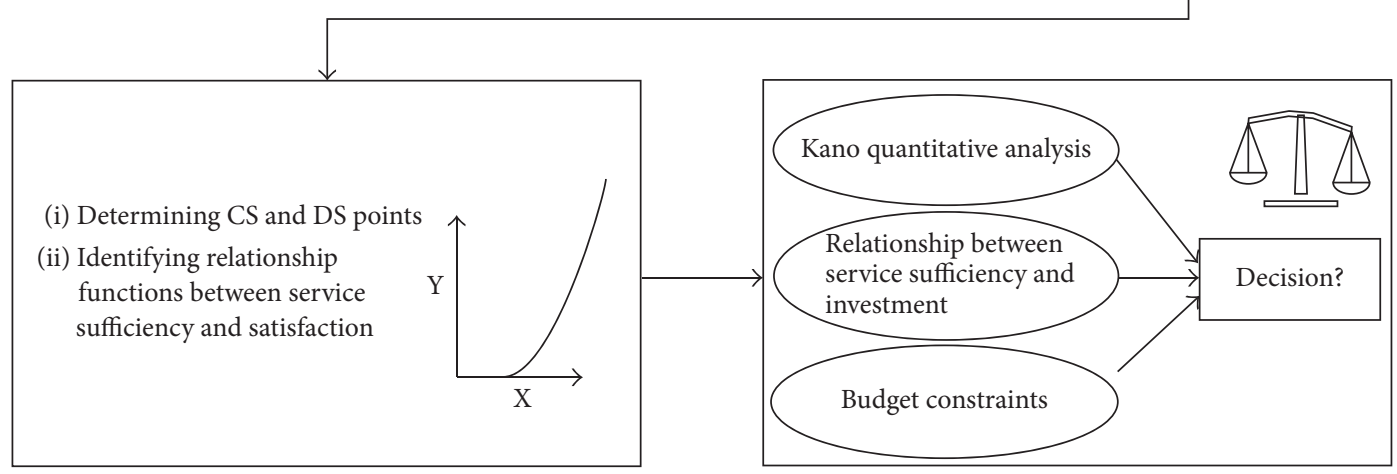

(4) Quantitative analysis of Kano model

(5) Decision model formulation

FIGURE 2: The proposed research framework.

fuzzy linguistics and fuzzy inference, and it is successfully used in fuzzy decision-making [55]. Thus, some scholars suggested incorporating the fuzzy set theory into Kano model to accommodate linguistic properties of subjective and vague human perception [22-24]. The fuzzy Kano model has been found capable of mimicking a realistic cognition process in practice. An evaluator's multiple feelings can be expressed by the possibility degrees in the fuzzy Kano model. In this study, we are inclined to use fuzzy Kano model to elicit customers' perception and gain classification results of service quality elements [55].

3.4. Quantitative Analysis of the Kano Model. After the classification results based on the fuzzy Kano model are obtained, the quantitative analysis is conducted as the literature of Wang and Ji (2010) [21].

Based on the findings of service quality elements classification, it is possible to calculate two values, namely, customer satisfaction (CS) and customer dissatisfaction (DS) [19]:

$$
\begin{aligned}
\mathrm{CS}_{i} & =\frac{f_{A}+f_{O}}{f_{A}+f_{O}+f_{M}+f_{I}}, \\
\mathrm{DS}_{i} & =\frac{f_{\mathrm{O}}+f_{M}}{f_{A}+f_{O}+f_{M}+f_{I}} .
\end{aligned}
$$

Let $f_{A}$ denote the number of attractive quality elements, $f_{O}$ the number of one-dimensional quality elements, $f_{M}$ the number of must-be quality elements, and $f_{I}$ the number of indifferent quality elements.

Consequently, the two points define the customer satisfaction if a quality element can be fully fulfilled or completely nonfulfilled. These points can be plotted as $\left(1, \mathrm{CS}_{i}\right)$ and $\left(0,-\mathrm{DS}_{i}\right)$ [21]. The relationship function between customer satisfaction and service quality element fulfillment can be identified given the category of the quality element. The relationship function can be expressed as $S=f(x, a, b)$, where $S$ denotes the customer satisfaction, $x$ denotes the fulfillment level, and $a$ and $b$ are adjustment parameters for the Kano categories of service quality elements. For onedimensional quality elements, the function is $S=a_{1} x+b_{1}$, and the shape of the linear curve must pass the CS and DS points. Then we can get $a_{1}=\mathrm{CS}_{i}-\mathrm{DS}_{i}$ and $b_{1}=\mathrm{DS}_{i}$. Therefore, the function for one-dimensional quality elements is

$$
S_{o i}=\left(\mathrm{CS}_{i}-\mathrm{DS}_{i}\right) x_{o i}+\mathrm{DS}_{i}
$$

For attractive quality elements, the function can be seen to be exponential; $S=a_{2} e^{x}+b_{2}$. Substituting $\left(1, \mathrm{CS}_{i}\right)$ and $\left(0,-\mathrm{DS}_{i}\right)$ into the equation, we can get $a_{2}=\left(\mathrm{CS}_{i}-\mathrm{DS}_{i}\right) /(e-1)$ and $b_{2}=-\left(\mathrm{CS}_{i}-e \mathrm{DS}_{i}\right) /(e-1)$. The function for attractive quality elements is therefore

$$
S_{a i}=\frac{\mathrm{CS}_{i}-\mathrm{DS}_{i}}{e-1} e^{x_{a i}}-\frac{\mathrm{CS}_{i}-e \mathrm{DS}_{i}}{e-1} .
$$

Using the similar approach, for must-be quality elements, the function is modified to be $S=-a_{3} e^{-x}+b_{3}$, and we can acquire $a_{3}=e\left(\mathrm{CS}_{i}-\mathrm{DS}_{i}\right) /(e-1)$ and $b_{3}=\left(e \mathrm{CS}_{i}-\mathrm{DS}_{i}\right) /(e-1)$. Then the function for must-be quality elements is

$$
S_{m i}=-\frac{e\left(\mathrm{CS}_{i}-\mathrm{DS}_{i}\right)}{e-1} e^{-x_{m i}}+\frac{e \mathrm{CS}_{i}-\mathrm{DS}_{i}}{e-1} .
$$

3.5. Decision Model Formulation. In this stage, a decision model for maximizing service quality under budget constraints is developed based on the quantitative Kano model. Different service quality element categories have different influence on satisfaction. Fulfilling customer expectations of service quality to a great extent does not necessarily guarantee a higher customer satisfaction. Sufficient provision will lead to increased costs. It is a very important task to seek for an efficient way to leverage the customer satisfaction and 


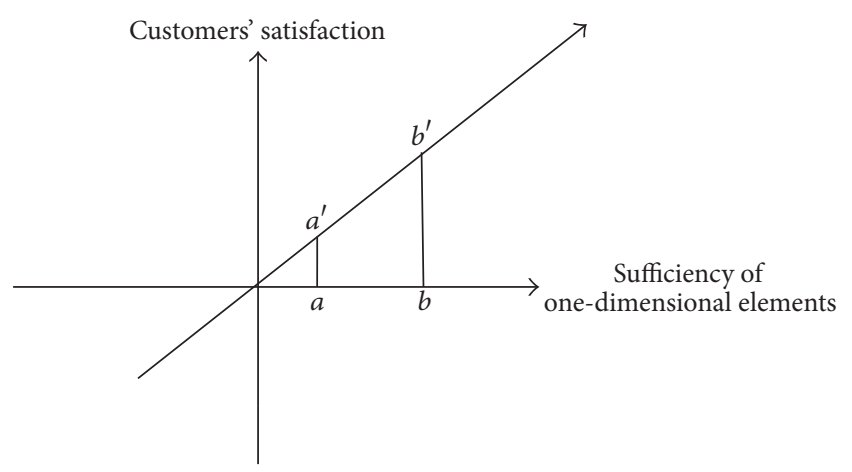

FIGURE 3: Sufficiency of one-dimensional elements and customers' satisfaction.

cost constraints. This will be done using a service quality maximization model, and its construction will be shown in the following section. Firstly, the relationships between sufficiencies of different service quality elements categories and customer satisfactions are discussed.

(i) One-Dimensional Quality Elements. Figure 3 shows the function for one-dimensional quality elements identified in Section 3.4. When the sufficiency is provided by $x_{o i}$ from level $a$ to $b$ resulting from one unit of monetary investment, the increased satisfaction, $A_{o}$, is the area $A_{o}$ surrounded by points $a, b, a^{\prime}$, and $b^{\prime}$, and it can be computed as

$$
A_{o}=\int_{a}^{b}\left[\left(\mathrm{CS}_{i}-\mathrm{DS}_{i}\right) x_{o i}+\mathrm{DS}_{i}\right] d x_{o i}
$$

When an enterprise provides $n$ one-dimensional service quality elements and if the sufficiency provided by each $x_{o i}$ increases from $a_{i}$ to $b_{i}$, then $T A_{o}$, the level of satisfaction increased by $n$ one-dimensional elements, can be expressed as

$$
\begin{array}{r}
T A_{o}=\sum_{i=1}^{n} A_{o i}=\sum_{i=1}^{n} \int_{a_{i}}^{b_{i}}\left[\left(\mathrm{CS}_{i}-\mathrm{DS}_{i}\right) x_{o i}+\mathrm{DS}_{i}\right] d x_{o i} \\
i=1,2, \ldots, n
\end{array}
$$

For simplicity, assuming that $a_{1}=a_{2}=\cdots=a_{n}=a, b_{1}=b_{2}=$ $\cdots=b_{n}=b$, the total increased customer satisfaction $T A_{o}$ provided by $n$ one-dimensional elements can be computed as

$$
T A_{o}=\sum_{i=1}^{n} \int_{a}^{b}\left[\left(\mathrm{CS}_{i}-\mathrm{DS}_{i}\right) x_{o i}+\mathrm{DS}_{i}\right] d x_{o i}
$$

(ii) Attractive Quality Elements. Figure 4 shows the example of an attractive quality element. The relationship function is $S_{a i}=\left(\left(\mathrm{CS}_{i}-\mathrm{DS}_{i}\right) /(e-1)\right) e^{x_{a i}}-\left(\mathrm{CS}_{i}-e \mathrm{DS}_{i}\right) /(e-1)$, and when the sufficiency is provided by $x_{a i}$ from level $c$ to $d$ resulting from one unit of monetary investment, the increased satisfaction $A_{a}$ surrounded by points $c, d, c^{\prime}$, and $d^{\prime}$ can be computed as

$$
A_{a}=\int_{c}^{d}\left(\frac{\mathrm{CS}_{i}-\mathrm{DS}_{i}}{e-1} e^{x_{a i}}-\frac{\mathrm{CS}_{i}-e \mathrm{DS}_{i}}{e-1}\right) d x_{a i}
$$

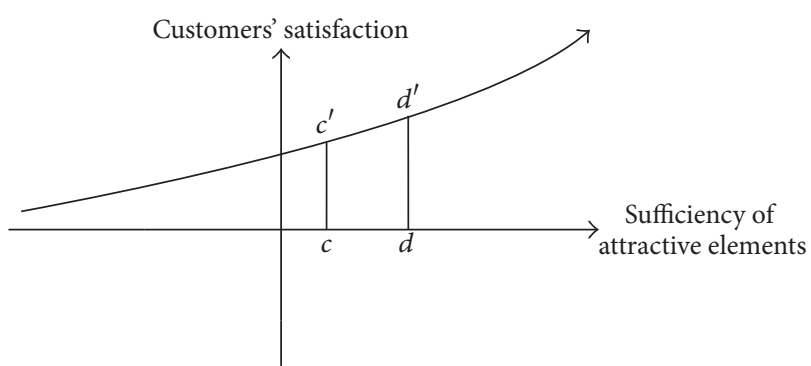

FIgURE 4: Sufficiency of attractive elements and customers' satisfaction.

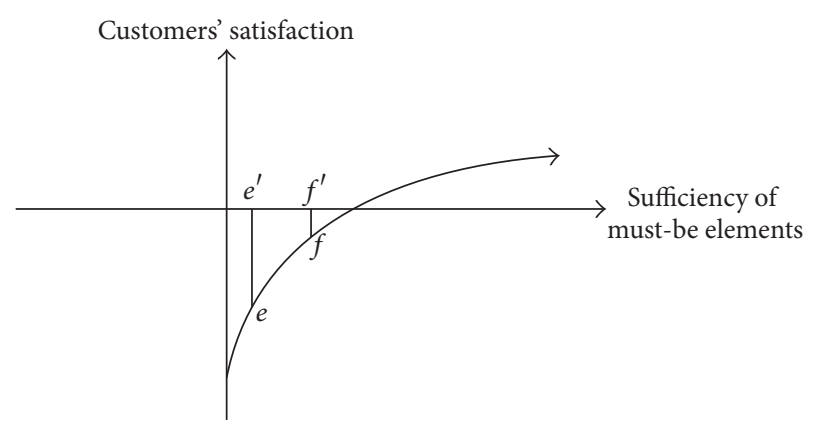

FIGURE 5: Sufficiency of must-be elements and customers' satisfaction.

If $n$ attractive quality elements provided, with the sufficiency of each $x_{a i}$, increase from $c_{i}$ to $d_{i}$, the increased satisfaction $T A_{a}$ can be expressed as

$$
\begin{aligned}
T A_{a}= & \sum_{i=1}^{n} A_{a} \\
= & \sum_{i=1}^{n} \int_{c_{i}}^{d_{i}}\left(\frac{\mathrm{CS}_{i}-\mathrm{DS}_{i}}{e-1} e^{x_{a i}}-\frac{\mathrm{CS}_{i}-e \mathrm{DS}_{i}}{e-1}\right) d x_{a i}, \\
& \quad i=1,2, \ldots, n .
\end{aligned}
$$

For the ease of manifestation, assuming that $c_{1}=c_{2}=\cdots=$ $c_{n}=c, d_{1}=d_{2}=\cdots=d_{n}=d$, the total increased satisfaction $T A_{a}$ can be simplified as

$$
T A_{a}=\sum_{i=1}^{n} \int_{c}^{d}\left(\frac{\mathrm{CS}_{i}-\mathrm{DS}_{i}}{e-1} e^{x_{a i}}-\frac{\mathrm{CS}_{i}-e \mathrm{DS}_{i}}{e-1}\right) d x_{a i} .
$$

(iii) Must-Be Quality Elements. As Figure 5 shows, the relationship function for must-be quality element is $S_{m i}=$ $-\left(e\left(\mathrm{CS}_{i}-\mathrm{DS}_{i}\right) /(e-1)\right) e^{-x_{m i}}+\left(e \mathrm{CS}_{i}-\mathrm{DS}_{i}\right) /(e-1)$, and when the sufficiency is provided by $x_{m i}$ from level $e$ to $f$ resulting from one unit of monetary investment, the decreased dissatisfaction $A_{m}$ surrounded by points $e, f, e^{\prime}$, and $f^{\prime}$ is computed as

$$
A_{m}=\int_{e}^{f}\left(-\frac{e\left(\mathrm{CS}_{i}-\mathrm{DS}_{i}\right)}{e-1} e^{-x_{m i}}+\frac{e \mathrm{CS}_{i}-\mathrm{DS}_{i}}{e-1}\right) d x_{m i} .
$$


If $n$ must-be quality elements provided, with the sufficiency provided by each $x_{m i}$, increase from $e_{i}$ to $f_{i}$, then the decreased dissatisfaction $T A_{m}$ can be expressed as

$$
\begin{aligned}
& T A_{m}=\sum_{i=1}^{n} A_{m} \\
& =\sum_{i=1}^{n} \int_{e_{i}}^{f_{i}}\left(-\frac{e\left(\mathrm{CS}_{i}-\mathrm{DS}_{i}\right)}{e-1} e^{-x_{m i}}+\frac{e \mathrm{CS}_{i}-\mathrm{DS}_{i}}{e-1}\right) d x_{m i}, \\
& i=1,2, \ldots, n .
\end{aligned}
$$

Assuming that $e_{1}=e_{2}=\cdots=e_{n}=e, f_{1}=f_{2}=\cdots=f_{n}=f$, the total decreased dissatisfaction $T A_{m}$ is simplified as

$$
\begin{aligned}
& \mathrm{TA}_{m} \\
& =\sum_{i=1}^{n} \int_{e}^{f}\left(-\frac{e\left(\mathrm{CS}_{i}-\mathrm{DS}_{i}\right)}{e-1} e^{-x_{m i}}+\frac{e \mathrm{CS}_{i}-\mathrm{DS}_{i}}{e-1}\right) d x_{m i} .
\end{aligned}
$$

The equations above now can be applied to improve the machinery service quality. There are many factors that can be related to the machinery service quality, and some fall into must-be elements, and others are one-dimensional or attractive quality elements. Moreover, the increased satisfaction resulting from investment on must-be, one-dimensional, and attractive quality elements is certainly different. Thus, the problem is how to properly allocate the budget to service quality elements in order to maximize the overall customer satisfaction. At this point the following model can be proposed:

$$
\begin{array}{ll}
M: \max & C_{o}\left(T A_{o}\right)+C_{a}\left(T A_{a}\right)+C_{m}\left(T A_{m}\right) \\
\text { s.t. } & C_{o}+C_{a}+C_{m} \leq B \\
& 0 \leq C_{o} \leq B \\
& 0 \leq C_{a} \leq B \\
& 0 \leq C_{m} \leq B \\
& C_{o}=k_{1}(b-a) \\
& C_{a}=k_{2}(d-c) \\
& C_{m}=k_{3}(f-e) \\
& 0 \leq a \leq b \leq D \leq 1 \\
& 0 \leq c \leq d \leq E \leq 1 \\
& 0 \leq e \leq f \leq F \leq 1
\end{array}
$$

where $C_{o}, C_{a}$, and $C_{m}$ denote the individual budget allocated to one-dimensional, attractive, and must-be quality elements and these are the decision variables. $B$ is the total budget to improve the overall service quality. When budgeted, $C_{o}$ can be increased from $a$ to $b$ with $D$ being the upper limit. With the same principles, $C_{a}$ can be increased from $c$ to $d$ with $E$ being the upper limit, and $C_{m}$ can be increased from $e$ to $f$ with $F$ being the upper limit. The coefficients of $k_{1}, k_{2}$, and $k_{3}$ stand for the relationship between budget allocated and the level of quality improvement. The nonlinear mathematical model can be solved by optimization software Lingo, and the details will be shown in the following illustrative example.

\section{An Empirical Study}

To demonstrate the performance of the proposed method, an empirical study in Xuzhou Construction Machinery Group Co., Ltd. (XCMG), is given in this section. XCMG is the largest construction machinery company in China. Its products cover road machineries, crane trucks, heavy-duty road rollers, and so on, which include 75 series and 330 varieties. The product sales network of XCMG covers more than 170 countries and regions, and the annual export value has exceeded \$1.6 Billion USD. But in recent years with the scale enlargement of markets and the implementation of the "Going Global" strategy, XCMG is facing much greater variety and uncertainty in customer requirement. XCMG now needs to explore the appropriate strategy on the service quality management to gain competitive advantage. Since 2011, XCMG launched the project of "Hanfeng Program" to establish a control system for service quality improvement. And the decision method proposed in this paper is implied in the program.

4.1. Service Quality Elements Identification in XCMG. Based on the SERVQUAL model, several experts in XCMG and some users are investigated by the team members, and twelve service quality elements and benefits provided for customers in XCMG are extracted in Table 2.

4.2. Data Collection and Analysis. According to the twelve service quality elements, the fuzzy Kano questionnaire is designed, which is divided into two parts: in the first part, there is some demographic information of respondents such as organization characters (state-owned business, private business, foreign-funded enterprise, or joint venture enterprise) and types of customers (general customers, key accounts, or strategic customers). In the second part, the questionnaire focuses on a set of 12 items of service quality elements, and the form of each item is presented with both functional and dysfunctional forms, but, unlike traditional Kano model using binary data, the fuzzy Kano model questionnaire allows respondents to express their multiple feelings by the possibility degrees among multiple items. Additional information on the fuzzy Kano questionnaire can be found in the literature [55].

The fuzzy Kano questionnaire is distributed randomly face-to-face by the employees from marketing department and after-sale service support department and team members in the program. The first step is to provide respondents with a brief introduction of Kano model, and then customers are asked to give multiple answers of the pair questions about service quality elements. From September 15 to December 15, 2012, 250 copies of the questionnaire have been issued and 196 completed copies are retrieved. This is a reasonable response rate of $78.4 \%$. The sample demographic characteristics are shown in Table 3. 
TABLE 2: Service quality elements and benefits provided for customers in XCMG

\begin{tabular}{|c|c|c|}
\hline $\begin{array}{l}\text { Service quality } \\
\text { elements }\end{array}$ & Description and specification & $\begin{array}{l}\text { Benefits } \\
\text { provided }\end{array}$ \\
\hline $\mathrm{SQ}_{1}$ & $\begin{array}{l}\text { Fulfill service commitments, } \\
\text { maintenance service in PLC }\end{array}$ & $\begin{array}{l}\text { Reliability, } \\
\text { safety }\end{array}$ \\
\hline $\mathrm{SQ}_{2}$ & $\begin{array}{l}\text { Quick response to } \\
\text { requirements and complaints }\end{array}$ & Speediness \\
\hline $\mathrm{SQ}_{3}$ & $\begin{array}{l}\text { Consultation and solutions } \\
\text { customization }\end{array}$ & $\begin{array}{l}\text { Empathy, added } \\
\text { value }\end{array}$ \\
\hline $\mathrm{SQ}_{4}$ & $\begin{array}{l}\text { Repair and maintenance } \\
\text { service covers widely }\end{array}$ & $\begin{array}{l}\text { Safety, } \\
\text { assurance, and } \\
\text { reliability }\end{array}$ \\
\hline $\mathrm{SQ}_{5}$ & $\begin{array}{l}\text { Machinery vehicles status } \\
\text { monitoring and warning, long } \\
\text { range information } \\
\text { transmission, and diagnosis }\end{array}$ & $\begin{array}{l}\text { Safety, } \\
\text { convenience }\end{array}$ \\
\hline $\mathrm{SQ}_{6}$ & Value-added service & $\begin{array}{l}\text { Added value, } \\
\text { empathy }\end{array}$ \\
\hline $\mathrm{SQ}_{7}$ & Network and online service & $\begin{array}{l}\text { Convenience, } \\
\text { speediness }\end{array}$ \\
\hline $\mathrm{SQ}_{8}$ & $\begin{array}{l}\text { Used machinery vehicles } \\
\text { business }\end{array}$ & $\begin{array}{l}\text { Convenience, } \\
\text { empathy }\end{array}$ \\
\hline $\mathrm{SQ}_{9}$ & $\begin{array}{l}\text { High quality service staffs' } \\
\text { professional and technical } \\
\text { abilities }\end{array}$ & $\begin{array}{l}\text { Pleasure, } \\
\text { assurance }\end{array}$ \\
\hline $\mathrm{SQ}_{10}$ & Compensation for delaying & $\begin{array}{l}\text { Reliability, } \\
\text { safety }\end{array}$ \\
\hline $\mathrm{SQ}_{11}$ & $\begin{array}{l}\text { Proactive services provided } \\
\text { regularly and periodically }\end{array}$ & $\begin{array}{l}\text { Convenience, } \\
\text { reliability }\end{array}$ \\
\hline $\mathrm{SQ}_{12}$ & $\begin{array}{l}\text { Customer participation in } \\
\text { service process }\end{array}$ & $\begin{array}{l}\text { Added value, } \\
\text { empathy }\end{array}$ \\
\hline
\end{tabular}

TABLE 3: Demographic characteristics of respondents.

\begin{tabular}{lcc}
\hline Demographic characteristics & Number & Percentage (\%) \\
\hline Organization characters & & \\
State-owned business & 54 & $27.55 \%$ \\
Private business & 43 & $21.94 \%$ \\
Foreign-funded enterprise & 47 & $23.98 \%$ \\
Joint venture enterprise & 52 & $26.53 \%$ \\
Types of customers & & \\
General customers & 79 & $40.31 \%$ \\
Key accounts & 65 & $33.16 \%$ \\
Strategic customers & 52 & $26.53 \%$ \\
\hline
\end{tabular}

4.3. Service Quality Elements Classification. Based on fuzzy Kano survey and statistical analysis, the classification results of service quality elements in XCMG are given from the preliminary qualitative results by the author [55], as is shown in Table 4.

4.4. Decision Results. According to results of service quality elements classification, the service quality elements, $\mathrm{SQ}_{11}$ (proactive services provided regularly and periodically) and $\mathrm{SQ}_{12}$ (customer participation in service process), are classified as indifferent quality elements. They are not included in the further analysis due to the low impact on customer satisfaction. At this point the proposed quantitative analysis in Section 3 is applied. Firstly, the values of CS and DS are computed for each service quality element as shown in Table 5. Based on the classification results in Table 4, the values of $a$ and $b$ are calculated to determine the function for each service quality element. Accordingly, all the relationship functions of three category quality elements are estimated in Table 5.

Given the data of cost for each service quality element drawn from investigation in XCMG, as is shown in Table 6, the total budget for service quality improvement is $¥ 150,000$.

Assuming $k_{1}=150, k_{2}=300, k_{3}=100, a=0.55, c=$ $0.55, e=0.55$, and $D=0.9, E=0.8$ and $F=1$. Then the model becomes

$$
\begin{aligned}
M: \max & C_{o}\left(T A_{o}\right)+C_{a}\left(T A_{a}\right)+C_{m}\left(T A_{m}\right) \\
\text { s.t. } & C_{o}+C_{a}+C_{m} \leq 150 \\
& 0 \leq C_{o} \leq 150 \\
& 0 \leq C_{a} \leq 150 \\
& 0 \leq C_{m} \leq 150 \\
& C_{o}=150(b-0.55) \\
& C_{a}=300(d-0.55) \\
& C_{m}=100(f-0.55) \\
& 0.55 \leq b \leq 0.9 \\
& 0.55 \leq d \leq 0.8 \\
& 0.55 \leq f \leq 1.0 \\
& T A_{o}=2.015 b^{2}-2.03 b+0.507 \\
& T A_{a}=1.32 e^{d}-2.25 d-1.0504 \\
& T A_{m}=8.88 e^{-f}+5.51 f-8.1538 .
\end{aligned}
$$

The nonlinear programming model is solved by Lingo 11.0, and the results are obtained as $C_{o}=52.5, C_{a}=52.5$, and $C_{m}=45 ; T A_{o}=0.31, T A_{a}=0.04$, and $T A_{m}=$ 0.62 ; and the overall customer satisfaction is 46.72 . It appears that XCMG should allocate $¥ 52,500$ to improve the onedimensional quality elements, with the level of service quality being improved from 0.55 to 0.9 . $¥ 52,500$ of the budget should be allocated for the attractive quality elements, with the level of service quality being improved from 0.55 to 0.725 . And $¥ 45,000$ should be allocated for the must-be quality elements, and it will improve the level of service quality from 0.55 to 1 .

To examine the appropriateness of the results, three different parameter values of coefficients $k_{i}$ are applied in the model for a sensitivity analysis. Due to the fact that the categories of service quality elements are the most effective factors on resource utilization, the sensitivity analysis focuses mainly on the coefficients $k_{i}$. Table 7 shows the results of the sensitivity analysis.

The results in Table 7 show that the coefficients $k_{i}$ have some effect on the decision-making results. In the three 
TABLE 4: Service quality elements classification results from Kano model.

\begin{tabular}{lcccccccccc}
\hline $\begin{array}{l}\text { Service quality } \\
\text { elements (number) }\end{array}$ & \multicolumn{4}{c}{ Traditional Kano model } & \multicolumn{4}{c}{ Fuzzy Kano model } \\
\hline $\mathrm{SQ}_{1}$ & 88 & 32 & 25 & 51 & $M$ & 106 & 38 & 18 & 44 & Category \\
$\mathrm{SQ}_{2}$ & 78 & 45 & 23 & 50 & $M$ & 98 & 42 & 20 & 51 & $M$ \\
$\mathrm{SQ}_{3}$ & 45 & 38 & 20 & 93 & $O$ & 51 & 43 & 25 & 99 & $O$ \\
$\mathrm{SQ}_{4}$ & 89 & 51 & 11 & 45 & $M$ & 95 & 56 & 15 & 37 & $M$ \\
$\mathrm{SQ}_{5}$ & 40 & 82 & 24 & 50 & $A$ & 46 & 88 & 27 & 53 & $A$ \\
$\mathrm{SQ}_{6}$ & 45 & 90 & 16 & 45 & $A$ & 49 & 92 & 18 & 48 & $A$ \\
$\mathrm{SQ}_{7}$ & 84 & 39 & 26 & 47 & $M$ & 95 & 52 & 24 & 38 & $M$ \\
$\mathrm{SQ}_{8}$ & 37 & 90 & 21 & 48 & $A$ & 39 & 48 & 19 & 92 & $O$ \\
$\mathrm{SQ}_{9}$ & 49 & 90 & 19 & 38 & $A$ & 54 & 46 & 24 & 95 & $O$ \\
$\mathrm{SQ}_{10}$ & 51 & 80 & 15 & 50 & $A$ & 84 & 56 & 13 & 47 \\
$\mathrm{SQ}_{11}$ & 38 & 59 & 80 & 19 & $I$ & 43 & 64 & 86 & 25 \\
$\mathrm{SQ}_{12}$ & 55 & 47 & 73 & 21 & $I$ & 56 & 48 & 78 & 22 & $I$ \\
\hline
\end{tabular}

TABLE 5: Quantitative results of service quality elements based on Kano model.

\begin{tabular}{lcccccccc}
\hline Number & CS & DS & CS point & DS point & $a$ & $b$ & $f(x)$ & $S=a f(x)+b$ \\
\hline $\mathrm{SQ}_{1}$ & 0.40 & -0.73 & $(1,0.4)$ & $(0,-0.73)$ & 1.78 & 1.05 & $e^{-x}$ & $S=-1.78 e^{-x}+1.05$ \\
$\mathrm{SQ}_{2}$ & 0.44 & -0.71 & $(1,0.44)$ & $(0,-0.71)$ & 1.81 & 1.11 & $e^{-x}$ & $S=-1.81 e^{-x}+1.11$ \\
$\mathrm{SQ}_{3}$ & 0.65 & -0.69 & $(1,0.65)$ & $(0,-0.69)$ & 1.34 & -0.69 & $x$ & $S=1.34 x-0.69$ \\
$\mathrm{SQ}_{4}$ & 0.46 & -0.65 & $(1,0.46)$ & $(0,-0.65)$ & 1.75 & 1.10 & $e^{-x}$ & $S=-1.75 e^{-x}+1.10$ \\
$\mathrm{SQ}_{5}$ & 0.66 & -0.46 & $(1,0.66)$ & $(0,-0.46)$ & 0.65 & -1.12 & $e^{x}$ & $S=0.65 e^{x}-1.12$ \\
$\mathrm{SQ}_{6}$ & 0.68 & -0.47 & $(1,0.68)$ & $(0,-0.47)$ & 0.67 & -1.13 & $e^{x}$ & $S=0.67 e^{x}-1.13$ \\
$\mathrm{SQ}_{7}$ & 0.43 & -0.64 & $(1,0.43)$ & $(0,-0.64)$ & 1.69 & 1.05 & $e^{-x}$ & $S=-1.69 e^{-x}+1.05$ \\
$\mathrm{SQ}_{8}$ & 0.71 & -0.66 & $(1,0.71)$ & $(0,-0.66)$ & 1.37 & -0.66 & $x$ & $S=1.37 x-0.66$ \\
$\mathrm{SQ}_{9}$ & 0.64 & -0.68 & $(1,0.64)$ & $(0,-0.68)$ & 1.32 & -0.68 & $x$ & $S=1.32 x-0.68$ \\
$\mathrm{SQ}_{10}$ & 0.52 & -0.66 & $(1,0.52)$ & $(0,-0.66)$ & 1.85 & 1.20 & $e^{-x}$ & $S=-1.85 e^{-x}+1.2$ \\
\hline
\end{tabular}

TABLE 6: Cost for each service quality element.

\begin{tabular}{llc}
\hline $\begin{array}{l}\text { Service quality } \\
\text { elements } \\
\text { (number) }\end{array}$ & Description and specification & $\begin{array}{c}\text { Costs } \\
(¥ 1000)\end{array}$ \\
\hline $\mathrm{SQ}_{1}$ & $\begin{array}{l}\text { Fulfill service commitments, } \\
\text { maintenance service in PLC } \\
\text { Quick response to requirements and } \\
\text { complaints }\end{array}$ & 4800 \\
$\mathrm{SQ}_{2}$ & $\begin{array}{l}\text { Consultation and solutions } \\
\text { customization }\end{array}$ & 295 \\
$\mathrm{SQ}_{3}$ & $\begin{array}{l}\text { Repair and maintenance service covers } \\
\text { widely }\end{array}$ & 400 \\
$\mathrm{SQ}_{4}$ & $\begin{array}{l}\text { Machinery vehicles status monitoring } \\
\text { and warning, long range information } \\
\text { transmission, and diagnosis }\end{array}$ & 360 \\
$\mathrm{SQ}_{5}$ & $\begin{array}{l}\text { Value-added service } \\
\text { Network and online service }\end{array}$ & 200 \\
$\mathrm{SQ}_{6}$ & $\begin{array}{l}\text { Used machinery vehicles business } \\
\mathrm{SQ}_{7}\end{array}$ & $\begin{array}{l}\text { High quality service staffs' professional } \\
\text { and technical abilities }\end{array}$ \\
$\mathrm{SQ}_{8}$ & Compensation for delaying & 310 \\
$\mathrm{SQ}_{9}$ & & 460 \\
$\mathrm{SQ}_{10}$ & & \\
\hline
\end{tabular}

conditions, the must-be quality elements will first achieve their targets (always $f=1$ ), and they must be allocated to the budget to be fully fulfilled, while the one-dimensional and attractive quality elements are quite different. The performance of must-be quality elements has the priority in service quality improvement. With a limited budget $(¥ 150,000)$ it can only be guaranteed that the must-be and one-dimensional quality elements achieve their goals, while the attractive quality elements cannot be assured.

4.5. Suggestions. From the results, it appears that XCMG should firstly invest in must-be quality elements to assure an entirely fulfilled system with limited resources. Specifically, XCMG will establish a service standard system to fulfill service commitments, provide the maintenance service in a product's life cycle, and assure these quality elements to a high level. XCMG must guarantee a quick response to service requirements and complaints from customers, and this can be done through the use of both a Customer Relationship Management (CRM) system and Mobile Internet Technology (MIT). The service quality element "repair and maintenance service covers widely" will be improved in a large scale 
TABLE 7: Solutions with different parameter values of $k_{i}$.

\begin{tabular}{lccccccccccccc}
\hline Number & $k_{1}$ & $k_{2}$ & $k_{3}$ & $C_{o}$ & $C_{a}$ & $C_{m}$ & $T A_{o}$ & $T A_{a}$ & $T A_{m}$ & $b$ & $d$ & $f$ & $\max C S$ \\
\hline 1 & 150 & 300 & 100 & 52.5 & 52.5 & 45 & 0.31 & 0.04 & 0.62 & 0.9 & 0.73 & $\mathbf{1}$ & 46.72 \\
2 & 100 & 150 & 300 & 0 & 15 & 135 & $3.75 * 10^{-5}$ & 0.02 & 0.62 & 0.55 & 0.65 & $\mathbf{1}$ & $\mathbf{8 4 . 3 4}$ \\
3 & 300 & 100 & 150 & 102.73 & 0.02 & 47.25 & 0.30 & 0 & 0.62 & 0.89 & 0.55 & $\mathbf{1}$ & 60.28 \\
\hline
\end{tabular}

with the business expansion. Meanwhile, "the network and online service" needs also to be investigated within the company, as poor service quality for this element leads to strong dissatisfaction. If the must-be quality elements are not fulfilled, it would be essential to provide compensation to customers that place complaints.

The one-dimensional elements of "consultation and solutions customization," "used machinery vehicles business," and "high quality service staffs' professional and technical abilities" should also be improved to a high level to maximize customer satisfaction for XCMG. Considering customers' heterogeneities, service customization and service specialization will be the general trend in the future. The service quality is significantly related with service staffs, and XCMG must make sure that there are a group of service employees with high levels of professional and technical abilities. In addition to the focus on must-be and one-dimensional elements, it is wise to seek for some effective ways to improve the attractive quality elements, if there is potential for additional monetary investment.

The decision method proposed is also practical and functional for other enterprises to improve service quality. Firstly, it is critical to better identify and understand service quality elements from customers' perspective. Secondly, it is necessary to account for the budget constraints in the decision-making of service quality improvement. Thirdly, with the limited budget, to maximize the overall customer satisfaction, the must-be quality elements must be allocated to the budget to be fully fulfilled and to achieve the targets.

\section{Conclusions}

Service quality has become one of the sources for competitive advantage, especially for some machinery industries transforming into product-service system providers. And more importantly, service quality is the crucial determinant of customer satisfaction and customer loyalty. This integrated framework, proposed for maximizing machinery industry service quality under budget constraints, involves service quality elements identification and classification, quantitative analysis of Kano model, and decision model formulation. It provides a guidance principle of "origin from customers, application for customers" for enterprises to manage service quality in the customers-dominated logic era. As Wang and Ji (2010) [21] stated before, it is important to provide a way for quantitative Kano model to be integrated with other mathematical models for optimizing customer-focused product or service design.

The contributions of this research can be summarized as follows. First, the decision method proposed provides a systematic and quantitative solution for improving service quality in machinery manufacturers to balance customer satisfaction and service costs. Second, the integrated framework gives a practical roadmap for enterprises to improve service quality with limited budgets, and it involves several key processes: service quality elements identification, classification, and service quality improvement decision-making. Finally, the results provide empirical evidence that must-be quality elements have higher priorities in budget allocation for quality improvement, compared with one-dimensional and attractive quality elements, under the limited budgets.

Yet, there are some limitations in this paper. Firstly, in the nonlinear programming model (14), the coefficients parameters which related the budgets to the level of quality improvement should be discussed further, using a large amount of historical data in the future. Secondly, in the empirical research, the perceptions varieties in classification of service quality elements from different customer segments are not considered. And it is significant for the enterprises to make decisions with different customer orientation. Finally, more empirical studies on the decision method should be conducted to test the applicability.

\section{Competing Interests}

The authors declare that there are no competing interests regarding the publication of this paper.

\section{Acknowledgments}

The support in language modification from Mikhail Gordon, doctoral candidate of Joseph M. Katz Graduate School of Business and College of Business Administration from University of Pittsburgh, is acknowledged. The research is supported by the National Social Science Fund of China under Grant 14CGL014 and China Postdoctoral Research Fund under Grant 2013M530353.

\section{References}

[1] H. Gebauer and E. Fleisch, "An investigation of the relationship between behavioral processes, motivation, investments in the service business and service revenue," Industrial Marketing Management, vol. 36, no. 3, pp. 337-348, 2007.

[2] R. Oliva and R. Kallenberg, "Managing the transition from products to services," International Journal of Service Industry Management, vol. 14, no. 2, pp. 160-172, 2003.

[3] S. L. Vargo and R. F. Lusch, "Evolving to a new dominant logic for marketing," Journal of Marketing, vol. 68, no. 1, pp. 1-17, 2004.

[4] H. Gebauer, R. Krempl, E. Fleisch, and T. Friedli, "Innovation of product-related services," Managing Service Quality, vol. 18, no. 4, pp. 387-404, 2008. 
[5] M. Alsmadi, B. Lehaney, and Z. Khan, "Implementing six sigma in Saudi Arabia: an empirical study on the fortune 100 firms," Total Quality Management and Business Excellence, vol. 23, no. 3-4, pp. 263-276, 2012.

[6] T. Baines, H. Lightfoot, J. Peppard et al., “Towards an operations strategy for product-centric servitization," International Journal of Operations \& Production Management, vol. 29, no. 5, pp. 494$519,2009$.

[7] A. Davies, "Moving base into high-value integrated solutions: a value stream approach," Industrial and Corporate Change, vol. 13, no. 5, pp. 727-756, 2004.

[8] S. Johnstone, A. Dainty, and A. Wilkinson, "Integrating products and services through life: an aerospace experience," International Journal of Operations and Production Management, vol. 29, no. 5, pp. 520-538, 2009.

[9] K. S. Pawar, A. Beltagui, and J. C. K. H. Riedel, "The PSO triangle: designing product, service and organisation to create value," International Journal of Operations \& Production Management, vol. 29, no. 5, pp. 468-493, 2009.

[10] V. Martinez, M. Bastl, J. Kingston, and S. Evans, "Challenges in transforming manufacturing organisations into productservice providers," Journal of Manufacturing Technology Management, vol. 21, no. 4, pp. 449-469, 2010.

[11] M. Szwejczewski, K. Goffin, and Z. Anagnostopoulos, "Product service systems, after-sales service and new product development," International Journal of Production Research, vol. 53, no. 17, pp. 5334-5353, 2015.

[12] E. E. Izogo and I.-E. Ogba, "Service quality, customer satisfaction and loyalty in automobile repair services sector," International Journal of Quality and Reliability Management, vol. 32, no. 3, pp. 250-269, 2015.

[13] F. Jacob and W. Ulaga, "The transition from product to service in business markets: an agenda for academic inquiry," Industrial Marketing Management, vol. 37, no. 3, pp. 247-253, 2008.

[14] N. Kano, N. Seraku, F. Takahashi, and S. H. Tsjui, "Attractive quality and must-be quality," Hinshitsu, vol. 14, no. 2, pp. 147156, 1984.

[15] F. Herzberg, "The motivation to work among finnish supervisors," Personnel Psychology, vol. 18, no. 4, pp. 393-402, 1965.

[16] M. Löfgren and L. Witell, "Two decades of using Kano's theory of attractive quality: a literature review," The Quality Management Journal , vol. 15, no. 1, pp. 59-75, 2008.

[17] A. Shahin, M. Pourhamidi, J. Antony, and S. Hyun Park, "Typology of Kano models: a critical review of literature and proposition of a revised model," International Journal of Quality \& Reliability Management, vol. 30, no. 3, pp. 341-358, 2013.

[18] T. Luor, H.-P. Lu, K.-M. Chien, and T.-C. Wu, "Contribution to quality research: a literature review of Kano's model from 1998 to 2012," Total Quality Management \& Business Excellence, vol. 26, no. 3-4, pp. 234-247, 2015.

[19] C. Berger, R. Blauth, D. Boger et al., "Kano's methods for understanding customer-defined quality," The Center for Quality of Management Journal, vol. 2, pp. 3-36, 1993.

[20] K. Matzler and H. H. Hinterhuber, "How to make product development projects more successful by integrating Kano's model of customer satisfaction into quality function deployment," Technovation, vol. 18, no. 1, pp. 25-38, 1998.

[21] T. Wang and P. Ji, "Understanding customer needs through quantitative analysis of Kano's model," International Journal of Quality and Reliability Management, vol. 27, no. 2, pp. 173-184, 2010.
[22] Y.-C. Lee and S.-Y. Huang, "A new fuzzy concept approach for Kano's model," Expert Systems with Applications, vol. 36, no. 3, pp. 4479-4484, 2009.

[23] C.-H. Wang, "Incorporating customer satisfaction into the decision-making process of product configuration: a fuzzy kano perspective," International Journal of Production Research, vol. 51, no. 22, pp. 6651-6662, 2013.

[24] Q. Meng, X. Jiang, and L. Bian, "A decision-making method for improving logistics services quality by integrating fuzzy Kano model with importance-performance analysis," Journal of Service Science and Management, vol. 8, no. 3, pp. 322-331, 2015.

[25] K. C. Tan and T. A. Pawitra, "Integrating SERVQUAL and Kano's model into QFD for service excellence development," Managing Service Quality: An International Journal, vol. 11, no. 6, pp. 418430, 2001.

[26] B. Baki, C. Sahin Basfirinci, A. R. Ilker Murat, and Z. Cilingir, "An application of integrating SERVQUAL and Kano's model into QFD for logistics services: a case study from Turkey," Asia Pacific Journal of Marketing and Logistics, vol. 21, no. 1, pp. 106126, 2009.

[27] K. C. Tan and X.-X. Shen, "Integrating Kano's model in the planning matrix of quality function deployment," Total Quality Management, vol. 11, no. 8, pp. 1141-1151, 2000.

[28] G. Tontini, "Integrating the Kano model and QFD for designing new products," Total Quality Management \& Business Excellence, vol. 18, no. 6, pp. 599-612, 2007.

[29] P. Ji, J. Jin, T. Wang, and Y. Chen, "Quantification and integration of Kano's model into QFD for optimising product design," International Journal of Production Research, vol. 52, no. 21, pp. 6335-6348, 2014.

[30] Y.-F. Kuo, “Integrating Kano's model into web-community service quality," Total Quality Management \& Business Excellence, vol. 15, no. 7, pp. 925-939, 2004.

[31] M. Hartono and T. K. Chuan, "How the Kano model contributes to Kansei engineering in services," Ergonomics, vol. 54, no. 11, pp. 987-1004, 2011.

[32] C. Llinares and A. F. Page, "Kano's model in Kansei Engineering to evaluate subjective real estate consumer preferences," International Journal of Industrial Ergonomics, vol. 41, no. 3, pp. 233246, 2011.

[33] L. Witell, M. Löfgren, and J. J. Dahlgaard, “Theory of attractive quality and the Kano methodology - the past, the present, and the future," Total Quality Management and Business Excellence, vol. 24, no. 11-12, pp. 1241-1252, 2013.

[34] P. Erto and A. Vanacore, "A probabilistic approach to measure hotel service quality," Total Quality Management, vol. 13, no. 2, pp. 165-174, 2002.

[35] S.-C. Ting and C.-N. Chen, "The asymmetrical and non-linear effects of store quality attributes on customer satisfaction," Total Quality Management, vol. 13, no. 4, pp. 547-569, 2002.

[36] C.-C. Yang, “The refined Kano's model and its application," Total Quality Management and Business Excellence, vol. 16, no. 10, pp. 1127-1137, 2005.

[37] L. Nilsson Witell and A. Fundin, "Dynamics of service attributes: a test of Kano's theory of attractive quality," International Journal of Service Industry Management, vol. 16, no. 2, pp. 152-168, 2005.

[38] W.-K. Chang, C.-C. Wei, and N.-T. Huang, "An approach to maximize hospital service quality under budget constraints," Total Quality Management and Business Excellence, vol. 17, no. 6, pp. 757-774, 2006. 
[39] L.-S. Chen, C.-H. Liu, C.-C. Hsu, and C.-S. Lin, "C-kano model: a novel approach for discovering attractive quality elements," Total Quality Management and Business Excellence, vol. 21, no. 11, pp. 1189-1214, 2010.

[40] J.-K. Chen and Y.-C. Lee, "A new method to identify the category of the quality attribute," Total Quality Management \& Business Excellence, vol. 20, no. 10, pp. 1139-1152, 2009.

[41] Y.-F. Kuo, C.-M. Wu, and W.-J. Deng, “The relationships among service quality, perceived value, customer satisfaction, and postpurchase intention in mobile value-added services," Computers in Human Behavior, vol. 25, no. 4, pp. 887-896, 2009.

[42] S. C. Chen, L. Chang, and T. H. Huang, "Applying six-sigma methodology in the Kano quality model: an example of the stationery industry," Total Quality Management and Business Excellence, vol. 20, no. 2, pp. 153-170, 2009.

[43] C.-C. Yang, "Identification of customer delight for quality attributes and its applications," Total Quality Management and Business Excellence, vol. 22, no. 1, pp. 83-98, 2011.

[44] Y. Xie, C. L. Hui, and S. F. Ng, "The evaluation of quality attributes of NPO products: a case in medical garments," Total Quality Management and Business Excellence, vol. 21, no. 5, pp. 517-535, 2010.

[45] L.-H. Chen and Y.-F. Kuo, "Understanding e-learning service quality of a commercial bank by using Kano's model," Total Quality Management \& Business Excellence, vol. 22, no. 1, pp. 99-116, 2011.

[46] M.-C. Tsai, L.-F. Chen, Y.-H. Chan, and S.-P. Lin, "Looking for potential service quality gaps to improve customer satisfaction by using a new GA approach," Total Quality Management \& Business Excellence, vol. 22, no. 9, pp. 941-956, 2011.

[47] Y.-F. Kuo, J.-Y. Chen, and W.-J. Deng, "IPA-Kano model: a new tool for categorising and diagnosing service quality attributes," Total Quality Management and Business Excellence, vol. 23, no. 7-8, pp. 731-748, 2012.

[48] R. Florez-Lopez and J. M. Ramon-Jeronimo, "Managing logistics customer service under uncertainty: an integrative fuzzy Kano framework," Information Sciences, vol. 202, pp. 41-57, 2012.

[49] G. Tontini and J. Dagostin Picolo, "Identifying the impact of incremental innovations on customer satisfaction using a fusion method between importance-performance analysis and Kano model," International Journal of Quality \& Reliability Management, vol. 31, no. 1, pp. 32-52, 2014.

[50] F.-Y. Chen and S.-H. Chen, "Application of importance and satisfaction indicators for service quality improvement of customer satisfaction," International Journal of Services, Technology and Management, vol. 20, no. 1-3, pp. 108-122, 2014.

[51] N. Bandyopadhyay, H. Estelami, and K. Eriksson, "Classification of service quality attributes using Kano's model: a study in the context of the Indian banking sector," International Journal of Bank Marketing, vol. 33, no. 4, pp. 457-470, 2015.

[52] A. Esmaeili, R. A. Kahnali, R. Rostamzadeh, E. K. Zavadskas, and B. Ghoddami, "An application of fuzzy logic to assess service quality attributes in logistics industry," Transport, vol. 30, no. 2, pp. 172-181, 2015.

[53] W. J. Regan, “The service revolution," The Journal of Marketing, vol. 27, no. 3, pp. 57-62, 1963.

[54] H. Güçdemir and H. Selim, "Integrating multi-criteria decision making and clustering for business customer segmentation," Industrial Management \& Data Systems, vol. 115, no. 6, pp. 10221040, 2015.
[55] Q. Meng, X. Jiang, L. He, and X. Guo, "Integration of fuzzy theory into Kano model for classification of service quality elements: a case study in a machinery industry of China," Journal of Industrial Engineering and Management, vol. 8, no. 5, pp. 1661-1675, 2015. 

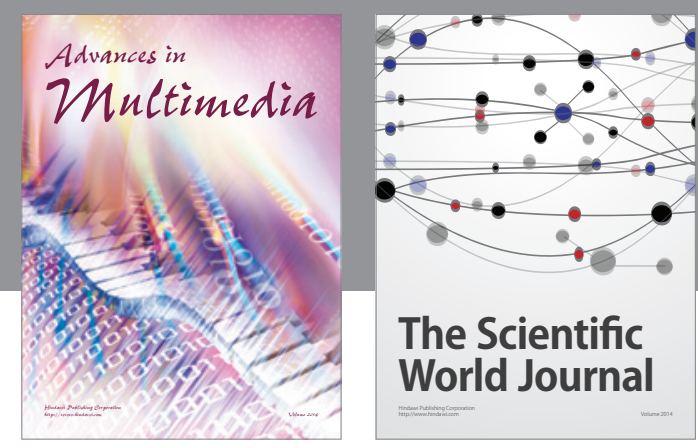

The Scientific World Journal
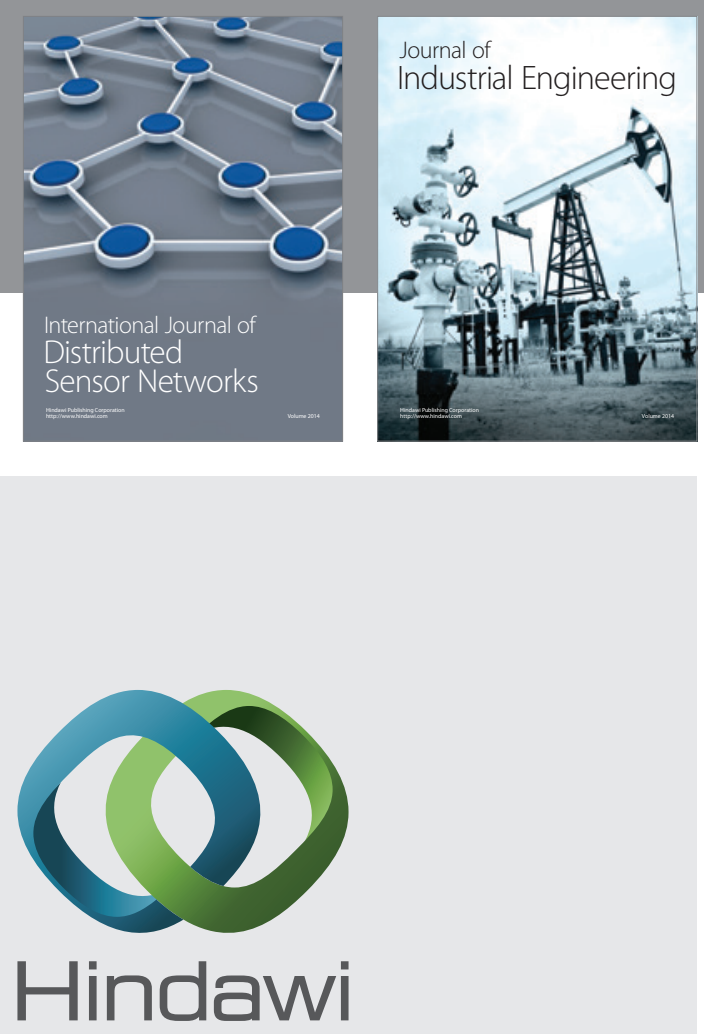

Submit your manuscripts at

http://www.hindawi.com

\section{Computer Networks} and Communications
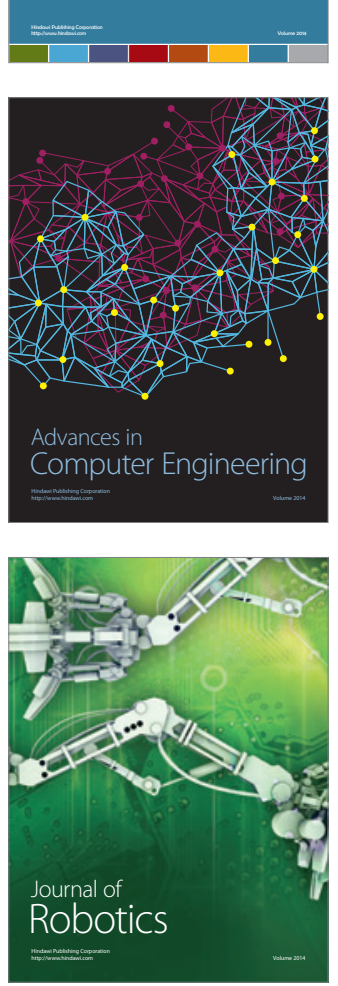
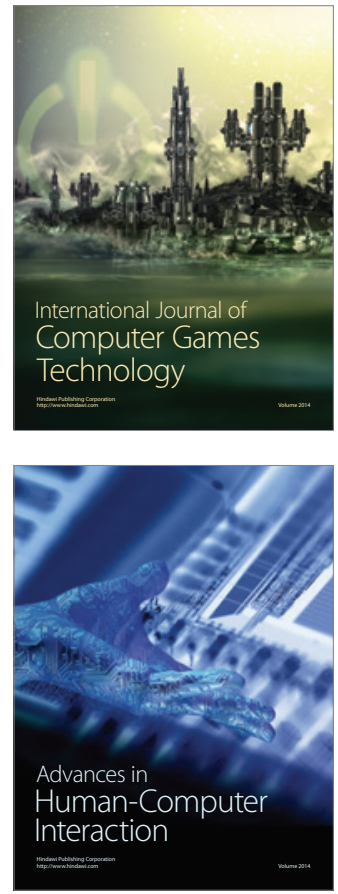
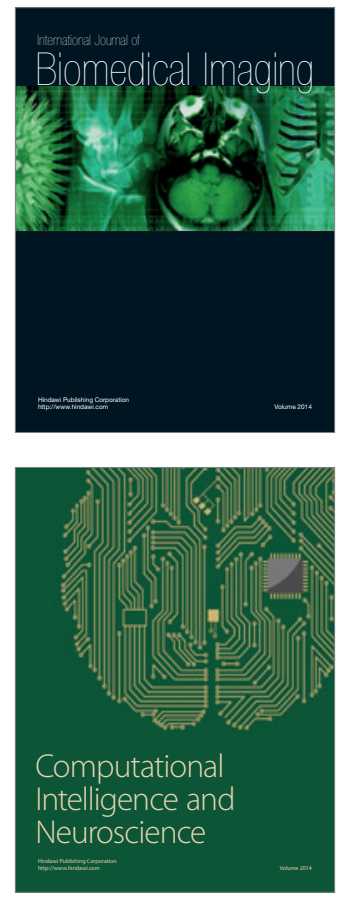
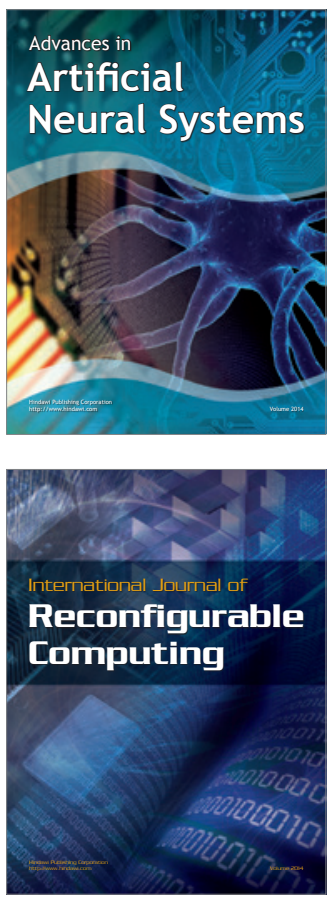
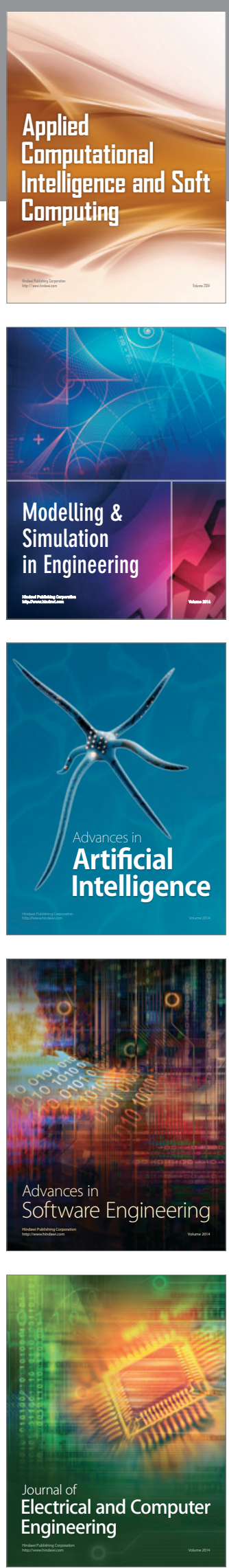